\title{
Informasjonen om mammografiscreening er ikke nøytral
}

\author{
Mammografiscreening har medført en stor økning i forekomsten av brystkreft i aldersgruppen 50-69 år. \\ Mye av økningen skyldes overdiagnostikk, noe kvinner blir dårlig informert om. Kreftregisteret forteller kun \\ om reduksjon i brystkreftdødelighet, og effekten overdrives. Mine beregninger tyder på at like mange eller \\ flere kvinner vil $d \emptyset$ av skader etter overbehandling som det antall som muligens vil reddes fra å d $\varnothing$ av bryst- \\ kreft. Det er således ingen reduksjon i totaldødelighet. Kvinner bør få informasjon om dette.
}

I 15 år har sentrale personer ved Kreftregisteret hevdet at mammografiscreening ville redusere brystkreftdødeligheten med rundt $50 \%$ (1), samtidig som overdiagnostikk (diagnostikk og behandling av små svulster som aldri ville blitt til klinisk sykdom) ikke representerte noe problem (2). Senest i år uttalte ledende personer ved registeret at screening redder to liv for hver kvinne som blir overdiagnostisert $(3,4)$.

I 1996, det året mammografiscreening ble innført, var det rundt 300 brystkreftdødsfall i aldersgruppen 55-74 år (5), den gruppen der man forventer redusert dødelighet $(6,7)$. Dette utgjør det maksimale antallet dødsfall som kan forebygges årlig. Kreftregisteret har selv publisert tall som viser at 428 kvinner årlig blir overdiagnostisert ved screening (8). Når de nå hevder at to dødsfall unngås per overdiagnostiserte kvinne, må dette bety at screening forebygger 856 brystkreftdødsfall årlig. Dette er nesten tre ganger flere enn antallet som døde av sykdommen før screeningen startet og en stor overdrivelse.

\section{Forholdet mellom unngåtte dødsfall og overdiagnostisering} Kalager og medarbeidere fant at dødeligheten av brystkreft i Norge falt med $10 \%$ som følge av innføring av mammografiscreening (6) og at dette tilsvarte 47 dødsfall over en tiårsperiode (9). Siden analysen ikke skiller mellom effekt av mammografiscreening og bedre behandling, er dette et maksimumestimat, og tallet er heller ikke statistisk signifikant. De samme forfatterne har også publisert at det var mellom 1169 og 1948 overdiagnostiserte kvinner i samme periode (9). Dette svarer til at 25-40 kvinner blir overdiagnostisert for hvert brystkreftdødsfall som forebygges.

Kalager og medarbeidere har beregnet $15-25 \%$ overdiagnostikk av infiltrerende brystkreft (9). $25 \%$ tilsvarer de nevnte 1948 overdiagnoser per 2237323 eksponeringsår eller 87 overdiagnosetilfeller per 100000 kvinner. Dette tilsvarer igjen litt under 500 overdiagnostiserte kvinner i Norge hvert år. Dette er det samme som vi hevdet i 2004 (10) og i 2012 (11). Tallet øker til rundt 750 når 250 forstadier inkluderes (11). Kalager og medarbeideres for- håndstall er således et meget konservativt anslag, fordi forstadier ikke er inkludert.

Forskjellen mellom Kreftregisterets anslag på én overdiagnostisert kvinne per to forebyggede dødsfall og andre forskeres anslag kan bare forklares med at man bruker fundamentalt ulike definisjoner av begrepet «overdiagnostikk» og forskjellige statistiske metoder. Noen mener at overdiagnostikk skal justeres for en teoretisk

\section{«Mammografi- screening er gammel- dags forebyggende medisin»}

«lead-time» $(8,12)$, som defineres som tiden diagnosen fremskyndes hvis man antar at ingen svulster slutter å vokse og $\mathrm{i}$ tillegg antar at kvinner ikke dør av andre årsaker enn brystkreft.

Begge antakelsene er urimelige. Det er også noe helt annet enn justering for tidlig diagnose og medfører at det prosentvise nivået på overdiagnostikk fortynnes dramatisk (12-14). Dette er forklaringen på at Kalager og medarbeideres estimat på $15-25 \%$ (9) og Zahl \& Mæhlens på $50 \%$ overdiagnostikk $(10,11)$ er forskjellig, mens det absolutte antall overdiagnoser er likt. Kreftregisteret bruker i tillegg statistiske modeller med en ukjent underliggende økning i forekomst av brystkreft som fortynner nivået på overdiagnostikk ytterligere (8). I et nylig publisert leserbrev blir de bedt om å angi hva de har antatt er den underliggende økning i brystkreftforekomst (15), men de har foreløpig ikke svart.

Ifølge mine beregninger (15) har de antatt en underliggende årlig økning på $2 \%$, $i$ en periode hvor man forventer en sterkt fallende forekomst av brystkreft fordi forbruket av hormoner mot plager i overgangsalderen har falt med $80 \%$ (11). Dette er en også en urimelig antakelse. I tillegg antar de at antall dødsfall av brystkreft som spares ved mammografiscreening er et titall ganger høyere enn det Kalager og medarbeidere har publisert (6). Til sammen medfører dette at forholdstallet mellom nytte og ulemper ved mammografiscreening som Kreftregisteret bruker i sin informasjon, er minst 50 ganger mer positivt enn det Kalager og medarbeidere finner.

\section{Totaldødelighet \\ ved mammografiscreening}

Mammografiscreening ble startet på grunnlag av randomiserte studier som nå er 40 år gamle $(7,12)$. Siden da er behandlingen av metastatisk sykdom blitt betraktelig bedre (16). Kvaliteten av en del av studiene er også dårlig på grunn av uklare eksklusjonskriterier $(7,13)$ og bruk av dødsårsaker som avviker fra den offisielle statistikken $(17,18)$. De randomiserte studiene med høy metodisk kvalitet viste selv den gang ingen signifikant reduksjon i brystkreftdødeligheten, og en systematisk oversikt viste ingen reduksjon i verken kreftdødelighet eller totaldødelighet (7).

I Kreftregisteret forholder man seg kun til brystkreftdødelighet som endepunkt, ikke til totaldødelighet $(1,3,4,19)$. Overdiagnostikken er omfattende og statistisk signifikant $(7-12,20)$ og vil etter min vurdering medføre økt dødelighet. Dersom de 750 kvinnene som blir overdiagnostisert blir behandlet med strålebehandling, vil noen dø av senvirkninger av denne. Stråledosene er betydelige, og oppfølgingsstudier av strålebehandlede brystkreftpasienter viser at de har $27 \%$ økt dødelighet av hjertesykdom og $78 \%$ økt dødelighet av lungekreft (21). Denne overdødeligheten har ikke falt de siste 50 årene (22).

I en gruppe på 750 kvinner kan man etter mine beregninger forvente 28 ekstra dødsfall av hjertesykdom og lungekreft i løpet av en 30-årsperiode (ramme 1) $(5,21$, $23,24)$. I tillegg kommer økt dødelighet av andre årsaker, deriblant bivirkninger av cellegift $(25,26)$. Dermed vil man forvente at minst like mange kvinner vil dø av skader etter overbehandling som de 30 kvinnene ( $10 \%$ av de $300 \mathrm{i}$ aldersgruppen 55-74 år som døde i 1996) som muligens blir reddet ved mammografiscreening. 


\section{RAMME 1}

\section{Forklaringer på økt dødelighet} ved overdiagnostisert brystkreft

Forutsetninger:

- I 2010 var det 525583 kvinner i aldersgruppen 60-89 år (5)

- Gjennomsnittlig alder ved diagnosetidspunkt i screeningprogrammet er 60 år (23)

- 750 kvinner overdiagnostiseres, hvorav to tredeler (500 kvinner) får strålebehandling unødig (24)

- 752 kvinner døde av ondartet kreft i lunger, bronkier, strupe og luftrør (C32-34) og 1477 døde av iskemisk hjertesykdom (I20-25) i denne aldersgruppen (5)

- Relativ risikoøkning for lungekreft og iskemisk hjertesykdom er 1,78 og 1,27 etter strålebehandling mot brystet (21)

Beregnet økt dødelighet basert på dette: Antall ekstra dødsfall av lungekreft: $500 \cdot(752 / 525583) \cdot 30$ år $\cdot 0,78=16,7$ Antall ekstra dødsfall av iskemisk hjertesykdom:

$500 \cdot(1477 / 525,583) \cdot 30$ år $\cdot 0,27=11,3$

\section{Konklusjon}

En systematisk oversikt har vist at de gamle randomiserte studiene som man støttet seg mest på, ikke er til å stole på (7) - data mangler og eller var forandret til fordel for mammografiscreening $(13,17,18)$. Screeningprogrammet har også lært oss at det finnes mange små svulster i brystet som aldri vil utvikle seg til klinisk sykdom og vil gå over av seg selv $(23,27)$. Dette informerer ikke Kreftregisteret om.

De fortsetter tvert imot med å informere offentligheten om reduksjon i årsakspesifikk dødelighet av brystkreft (og ikke totaldødelighet). De bruker tall som blir mer og mer ekstreme $(1,3,4,19)$ i forhold til hva uavhengige forskere publiserer $(6,7,9,10,12)$. Interessekonflikter oppgis ikke $(8,13)$, grunnleggende antakelser og statistiske justeringer er urimelige $(8,15)$, og tallene som brukes er selvmotsigende $(13,28,29)$. Spesielt er anslagene av overdiagnostikk i forhold til dødelighetsreduk- sjon etter min vurdering en ekstrem overdrivelse. Dette kan vi ikke leve med. Kvinner trenger nøytral opplysning for å kunne ta et informert valg om hvorvidt de skal delta i screening eller ikke.

Mammografiscreening er gammeldags forebyggende medisin som jeg mener ikke lenger kan forsvares. Det er på tide at helsemyndighetene avslutter en virksomhet som skader så mange friske kvinner og som ikke reduserer totaldødeligheten.

\section{Per-Henrik Zahl}

per-henrik.zahl@fhi.no

Per-Henrik Zahl (f. 1961) er dr.med. i biostatistikk og arbeider som statistiker ved Nasjonalt folkehelseinstitutt. Han har publisert flere artikler om mammografiscreening og brystkreftdødelighet.

Forfatter har fylt ut ICMJE-skjemaet og oppgir ingen interessekonflikter.

\section{Litteratur}

1. Bakke KA. Kan halvere dødeligheten ved brystkreft. Dagens Medisin 1/1998. http://www. dagensmedisin.no/nyheter/kan-halveredodeligheten-ved-brystkreft/ (18.6.2013).

2. Hofvind S, Møller B, Weedon-Fekjær H. Unjustified conclusion on overdiagnosis. BMJ 2004. http:// bmj.bmjjournals.com/cgi/eletters/328/7445/921 (18.6.2013).

3. Ursin G, Damtjernhaug B. Mammografiscreening redder liv. Aftenposten 21.2.2013.

4. Hofvind S. Organisert mammografiscreening flere fordeler enn ulemper. Tidsskr Nor Legeforen 2013; 133: 619-20.

5. Statistisk sentralbyrå. Dødsårsaksregisteret. https://www.ssb.no/statistikkbanken (18.6.2013)

6. Kalager M, Zelen M, Langmark F et al. Effect of screening mammography on breast-cancer mortality in Norway. N Engl J Med 2010; 363: 1203-10.

7. Gøtzsche PC, Nielsen M. Screening for breast cancer with mammography. Cochrane Database Syst Rev 2011; 1: CD001877.

8. Falk RS, Hofvind S, Skaane P et al. Overdiagnosis among women attending a population-based mammography screening program. Int J Cancer 2013; 133: 705-12.

9. Kalager M, Adami H-O, Bretthauer M et al. Overdiagnosis of invasive breast cancer due to mammography screening: results from the Norwegian screening program. Ann Intern Med 2012; 156: 491-9.

10. Zahl P-H, Strand BH, Maehlen J. Incidence of breast cancer in Norway and Sweden during introduction of nationwide screening: prospective cohort study. BMJ 2004; 328: $921-4$.

11. Zahl P-H, Mæhlen J. Overdiagnostikk av brystkreft etter 14 år med mammografiscreening. Tidsskr Nor Legeforen 2012: 132: 414-7.

12. Marmot MG, Altman DG, Cameron DA et al. The benefits and harms of breast cancer screening: an independent review. Lancet 2012; 380: 1778-86.

13. Gøtzsche PC. Mammography screening: truth, lies and controversy. London: Radcliffe Publishing; 2012.

14. Welch HG. 1 in 4 cancers detected at mammography screening are pseudocancers. BMJ 2006. www.bmj.com/content $/ 332 / 7543 / 689$ ?tab= responses (18.6.2013)

15. Zahl PH, Suhrke P, Jørgensen KJ. Overdiagnosis of breast cancer in Norway: What have the authors adjusted for? Int J Cancer 2013. E-publisert 3.5.

16. Early Breast Cancer Trialists' Collaborative Group Tamoxifen for early breast cancer: an overview of the randomised trials. Early Breast Cancer Trialists' Collaborative Group. Lancet 1998; 351: $1451-67$.

17. Gøtzsche PC, Maehlen J, Zahl P-H. What is publication? Lancet 2006; 368: 1854-6.

18. Zahl P-H, Gøtzsche PC, Andersen JM et al. Results of the Two-County trial of mammography screening are not compatible with contemporaneous official Swedish breast cancer statistics. Dan Med Bull 2006; 53: 438-40

19. Hofvind S, Ursin G, Tretli S et al. Breast cancer mortality in participants of the Norwegian Breast Cancer Screening Program. Cancer 2013. E-publisert 29.5.

20. Bleyer A, Welch HG. Effect of three decades of screening mammography on breast-cancer incidence. N Engl J Med 2012; 367: 1998-2005.

21. Clarke M, Collins R, Darby $S$ et al. Effects of radiotherapy and of differences in the extent of surgery for early breast cancer on local recurrence and 15-year survival: an overview of the randomised trials. Lancet 2005; 366: 2087-106.

22. Darby SC, Ewertz M, McGale P et al. Risk of ischemic heart disease in women after radiotherapy for breast cancer. N Engl J Med 2013; 368: 987-98.

23. Zahl P-H, Maehlen J, Welch HG. The natural history of invasive breast cancers detected by screening mammography. Arch Intern Med 2008; 168 2311-6.

24. Suhrke P, Mæhlen J, Schlichting E et al. Effect of mammography screening on surgical treatment for breast cancer in Norway: comparative analysis of cancer registry data. BMJ 2011; 343: d4692.

25. Fang F, Fall K, Mittleman MA et al. Suicide and cardiovascular death after a cancer diagnosis. N Engl J Med 2012; 366: 1310-8.

26. Shapiro CL, Recht A. Side effects of adjuvant treatment of breast cancer. N Engl J Med 2001; 344: 1997-2008

27. Zahl P-H, Gøtzsche PC, Mæhlen J. Natural history of breast cancers detected in the Swedish mammography screening programme: a cohort study. Lancet Oncol 2011; 12: 1118-24.

28. Gøtzsche PC, Jørgensen KJ, Zahl P-H. Breast screening: why estimates differ by a factor of 20-25. J Med Screen 2010; 17: 158-9, author reply $159-60$.

29. Gøtzsche PC, Jørgensen KJ, Zahl P-H et al. Why mammography screening has not lived up to expectations from the randomised trials. Cancer Causes Control 2012; 23: 15-21.

Mottatt 19.4. 2013, første revisjon innsendt 6.6. 2013, godkjent 2.7. 2013. Medisinsk redaktør Kristin Viste.

Publisert først på nett. 